\author{
Sławomir FRANEK, Professor \\ Faculty of Economics and Management, University of Szczecin \\ e-mail: sfranek@wneiz.pl \\ ORCID: 0000-0002-9698-4918
}

DOI: $10.15290 /$ oes.2018.03.93.06

\title{
DIVERSITY OF PUBLIC FINANCE MANAGEMENT INSTRUMENTS IN EU COUNTRIES
}

\begin{abstract}
Summary
The aim of the paper is to evaluate the implementation of public management instruments such as: independent fiscal institutions, fiscal rules and medium-term budgetary frameworks, with reference to the requirements set by EU legislation. The author uses a comparative analysis of the solutions applied in individual EU countries - based on the database of independent fiscal institutions, fiscal rules and medium-term budgetary frameworks published by the European Commission.

EU regulations ('six-pack', 'two-pack') are described as regards the implementation of independent fiscal institutions, fiscal rules and medium-term budgetary frameworks. On the basis of a literature review, the influence of these instruments on the creation of fiscal stability conditions is assessed. The conducted analysis of the solutions applied in individual countries made it possible to indicate the lack of a uniform model for the functioning of individual instruments in EU countries. Additionally, it was found that the highest dynamics of these instruments can be observed in those countries which have experienced significant fiscal tensions in recent years.
\end{abstract}

Keywords: independent fiscal institutions, fiscal rules, medium-term budgetary framework

JEL classification: H61, H50, E62

\section{Introduction}

The fiscal reforms implemented in the countries of the European Union in recent years have focused largely on the reinforcement of fiscal frameworks. This is reflected in the promotion of modern public finance management instruments, among which a particularly important part is played by: independent fiscal institutions (public institutions without party affiliation, established in order to prepare budget forecasts, monitor the compliance of fiscal policy with fiscal rules, and offer advice in terms of fiscal policy), fiscal rules (i.e. permanent restrictions of fiscal policy expressed in the form of synthetic measures defining acceptable values of basic budget parameters), and medium-term budget frameworks (understood as solutions extending the horizon of fiscal policy beyond the budget year). In its 
reports, the European Commission has repeatedly indicated the key role of these instruments in creating conditions for ensuring fiscal stability. This is reflected in the provisions introduced by the $\mathrm{EU}$ in the last decade to reinforce the process of constructing the budgets of the member states, which has prompted an evolution of the solutions in this area in many EU countries. The aim of this paper is to evaluate the implementation of particular public finance management instruments, such as independent fiscal institutions, fiscal rules and medium-term budget frameworks, taking into consideration the requirements indicated in the Council Directive 2011/85/ EU of 8 November on requirements for budgetary frameworks of the Member States and the Regulation (EU) no. 473/2013 of the European Parliament and of The Council of 21 May 2013 on common provisions for monitoring and assessing draft budgetary plans and ensuring the correction of excessive deficit of the Member States in the euro area. In order to achieve this, comparative analysis of the solutions used in particular countries was conducted on the basis of data published by the European Commission and regarding independent fiscal institutions, fiscal rules, and medium-term budgetary frameworks.

\section{Influence of fiscal instruments on fiscal stability: A review of literature}

The implementation of modern financial management instruments is justified by the universal tendency to generate deficits (deficit bias), combined with the low credibility of budget forecasts. Since one of the main objectives of public finance management is to ensure fiscal stability, it is necessary to use in the process of state governance such instruments which contribute to greater stability of this sector. This is consistent with the approach to public finance management presented in the publications of K. Piotrowska-Marczak [2011, pp. 9-29] and M. Postuła [2015]. A report published by ECOFIN on 20 March 2005, entitled "Improving the implementation of the Stability and Growth Pact", indicates the necessity to create budget forecasts on the basis of realistic and careful macroeconomic forecasts. There is comprehensive literature about the analysis of differences between budget plans and their implementation. It concerns such aspects as: the degree and direction of the deviation of budget parameters from predicted values, the impact of political and institutional factors on these deviations, the quality of macroeconomic forecasts of particular institutions, the transparency of the forecasting process. There can be observed two major threads of research. The first regards the quality of budget forecasts included in Stability and Growth Programmes, treated as economic forecasts, and testing their impartiality and practicability [Strauch Hallenberg, von Hagen, 2004; Annett, 2006; Jonung, Larch, 2006, pp. 491-534]. The second thread is focused on the political nature of the objectives included in these programmes which can be interpreted as the expression of the fiscal intentions of governments in the medium-term perspective [von Hagen, 2010, pp. 487-503]. This means that the discrepancies between fiscal plans and their implementation may be, on the one hand, a result of unexpected changes in economic situation and, on the other hand, they may result from the changes of political intentions. Therefore, at 
least some deviations from the declared fiscal objectives ought not to be seen as mistakes in the forecast, but as intentional steps. Fluctuations of the business cycle also have a major impact on the quality of budget forecasts. It has been observed that in the countries of the European Union, budget balance forecasts are particularly optimistic in times of prosperity, whereas downturns make forecasters far more cautious [Annett, 2006]. Moulin and Wierts [2006, pp. 983-1005] emphasise the special role of deviations from planned budget expenditure. Their conclusions have been confirmed by Beetsma, Giuliodori, Wierts [2009, pp. 753804] and Holm-Hadulla, Hauptmeier, Rother [2010], who have noticed that discretionary expenditures tend to exceed the levels assumed in budget plans.

Therefore, many authors suggest that independent fiscal institutions ensure more realistic budget plans in the medium term and minimize the risk of delays in fiscal consolidation. These activities are also affected by institutional solutions regarding public finance management. Particularly in countries where ministries of finance have full authority to create budget forecasts, there is greater prognostic optimism, while in countries with strong fiscal rules much more cautious forecasts predominate. Thus, strong fiscal rules [Abbas et al., 2011; Frankel, Schreger, 2013, pp. 247272] as well as strong legitimacy of fiscal transparency and medium-term fiscal rules [Beetsma et al., 2011] are conducive to prudence in formulating budget forecasts.

Debrun and Kinda [2014] prove that only strong and independent fiscal institutions help enhance fiscal results and increase the accuracy of forecasts. They also identify the following factors which have an influence on the position of these institutions: independence of functioning, presence in public debate, authority to monitor fiscal rules, participation in creating official forecasts. Hence, it can be assumed that independent fiscal institutions reduce the asymmetry of information between the politicians who make fiscal decisions and the public opinion.

There are numerous studies that prove the positive influence of the current fiscal rules on ensuring fiscal discipline. This is confirmed, among others, in the publications of such authors as: Alesina and Bayoumi [1996], Brzozowski and SiwińskaGorzelak [2010, pp. 205-231], Tapsoba [2012, pp. 1356-1369]. According to Nerlich and Reuter [2013], the most efficient rules are those regarding budget balance and those with a strong legal basis. Their research shows that the efficiency of rules increases when they are reinforced by the activity of independent fiscal councils.

Numerous publications have shown that fiscal rules enhance the pro-cyclical effect of fiscal policies, especially because of the pressure to limit investment expenditures in periods of economic slowdown [Dessus, Diaz Sanchez, Varoudakis, 2013; Arezki, Ismail 2013, pp. 256-267]. Heinemann, Osterloh, Kalb [2014] argue that rules may considerably increase the trust of financial markets towards countries with poor reputation.

At the same time, in recent years attention has been drawn to the fact that the evolution of fiscal rules towards greater flexibility and adjustment of corrective mechanisms dependent on the economic situation contributes to reinforcing their anti-cyclical character, which is proved by the results of the research conducted by Bergman and Hutchison [2015] and by Guerguil, Mandon, Tapsoba [2017, pp. 189-220]. 
On the basis of empirical studies comprising 74 countries (conducted in the years 1985-2012), Badinger and Reuter [2017, pp. 334-343] conclude that countries with stronger fiscal rules enjoy lower levels of budget deficit and lower spread in the interest rates of government bonds. The authors also underline that the introduction of fiscal rules diminishes the changeability of fiscal policy and is synonymous with greater stability of economic growth.

Similar conclusions can be drawn in the case of using medium-term fiscal frameworks. On the basis of research comprising 120 countries, Vlaicu et al. [2014, pp. 79-95] observe that extending the horizon of budget planning leads to reducing the deficit by 2 percent points on average.

Therefore, it can be said that there is ample evidence of the impact of using instruments of public finance management on the improvement of fiscal stability. Particular attention should be paid to the fact that numerous studies emphasise the importance of considering particular instruments jointly.

\section{Public finance management instruments in EU law}

Fiscal instruments were first legally recognised by the European Union in the Council Directive 2011/85/EU of 8 November 2011 on requirements for budgetary frameworks of the Member States (as one of the components of the so-called 'six-pack'). The Directive pointed out that the frameworks of the EU's budget supervision should be strengthened by strong numerical fiscal rules which would be efficiently and timely monitored. These rules ought to be based on credible and independent analysis conducted by self-contained institutions or organs functionally independent of the budget authorities of the member states. Additionally, the document stresses the necessity of multi-annual budget planning resulting from medium-term budget frameworks comprising at least a three-year budget plan in order to make certain that national budgets are planned in a multi-annual perspective. Additionally, it was decreed that the budget acs passed each year must comply with the provisions of mediumterm budgetary frameworks, while all the derogations from this principle ought to be justified.

These provisions were further detailed in the Regulation of the European Parliament and of the Council (EU) no. 473/2013 of 21 May 2013 on common provisions for monitoring and assessing draft budgetary plans and ensuring the correction of excessive deficit of the Member States in the euro area (as part of the so-called 'two-pack'). They chiefly concerned the preparation of realistic budget forecasts as it was assumed that biased and non-realistic macroeconomic and budget forecasts may considerably affect the efficiency of budget planning, which, in turn, may have a negative influence on budget discipline. Therefore, it was emphasised that only independent organs or organs functionally independent of state authorities, functioning on the basis of national laws which ensures a high level of functional independence and responsibility for undertaken activities, would ensure unbiased and realistic macroeconomic forecasts. 
Furthermore, the member states were obliged to establish independent bodies responsible for monitoring and assessing the compliance of the conducted fiscal policy with the existing fiscal rules. It was also decided that national medium-term budget plans and draft budgets ought to be based on independent macroeconomic forecasts and need to indicate whether budget forecasts have been prepared or confirmed by an independent body. Moreover, the necessity to make these forecasts public was emphasised.

The role of independent fiscal institutions was specified in Common principles on national fiscal correction mechanisms (COM/2012/0342) issued on the basis of Art. 3, par. 2 of the Treaty of stability, coordination and governance in the Economic and Monetary Union of 2 March 2012 (Journal of Acts of 2013, item 1258). These documents provide that independent bodies, or functionally autonomous bodies performing the function of monitoring institutions, contribute to the credibility and transparency of the corrective mechanism included in the fiscal rule. They should publicly assess whether:

- there exist circumstances justifying the activation of corrective mechanisms;

- corrections which have taken place are in line with national principles and plans; and

- $\quad$ any circumstances have occurred to justify the triggering, extending and exiting of escape clauses.

The document also obliges the member states to comply with the decisions of these bodies, and should they fail to do so, to provide public explanation for the non-compliance with the instructions resulting from the assessment.

These provisions constitute a formal basis for implementing in the member states mechanisms aiming at the reinforcement of institutional solutions contributing to the process of budget preparation. On the basis of these regulations and the experiences of those member states which had previously made the effort to use modern instruments for managing their budgetary allocations, the role of these instruments has been largely reinforced in recent years, virtually in all the member states. However, a substantial diversity of approaches can be observed and the lack of a single dominating model.

\section{Differences in the functioning of independent fiscal institutions}

Even though independent fiscal institutions are similar in terms of the scope of the tasks they realise, especially under the influence of EU laws, they widely differ in terms of their organisation in particular countries. This also concerns the implementation of tasks which exceed the scope specified in EU provisions. Some countries attempt to impose tasks which are the obligation of independent fiscal institutions on entities established earlier by extending the range of their activity. This is justified by the need to optimise the available material and staff resources, but it should be ascertained that these entities remain independent. Such a solution makes it possible to take advantage of the already strong institutions to build greater trust 
towards new tasks. In other countries, entirely new entities were formed. After 2013, this happened in seven countries (Bulgaria, Cyprus, Czech Republic, Greece, Luxembourg, Malta, and Slovenia). However, it should be noted that the Regulation of the European Parliament and of the Council (EU) no. 473/2013 allows for more than one independent organ to be responsible for monitoring compliance with fiscal rules in particular countries. At the same time, it stipulates that the responsibilities of particular organs referring to certain aspects of monitoring must be clearly divided.

Among independent fiscal institutions, three groups can be distinguished. The first includes entities which have functioned for several years and which specialise in creating both macroeconomic and budget forecasts. As examplescan serve the Dutch CPB (Centraal Planbureau) or the Austrian WIFO (Österreichisches Institut für Wirtschaftsforschung). These institutions have highly qualified staff and expertise, which enable them to formulate objective opinions on fiscal policies. The only change that they underwent after their actions had been subordinated to the requirements of the 'two-pack' was greater formalisation of the inclusion of the forecasts they prepare into the budget process. It needs to be mentioned that participation in the budget process may be associated with additional external pressure, posing a threat to the independence of performed activities. The second group of institutions comprises those more involved in the assessment of fiscal policies. Therefore, they can be identified with monitoring institutions. A good example is the Finnish National Audit Office (Valtiontalouden Tarkastusvirasto), for which the assessment of fiscal policy in terms of respect for fiscal rules became a new sphere of activity. Yet, it has to be mentioned that in order to ensure independent assessment, the introduction of the new task took place simultaneously with the selection of staff responsible for its realisation (within the Performance and Fiscal Policy Audit Department). The third group is the closest to the original status of independent fiscal institutions as fiscal councils, an example of which is the Swedish Fiscal Council (Finanspolitiska rädet). Among such institutions there are ones established in recent years: in Slovakia (Rada pre rospoctovú zodpovednost), Slovenia (Fiskalni svet), Romania (Consiliului Fisca), or Spain (Autoridad Independiente de Responsabilidad Fiscal). Their mandates are closely related to the provisions of the 'two-pack', whereas their development is strictly shaped by the need for fiscal consolidation faced by countries where these institutions began to function. In this group, one can observe a wide range of realised tasks (some even supervise the activity of local government units and state-owned enterprises), although making forecasts was frequently excluded from these tasks.

Table 1 presents the range of tasks carried out by independent fiscal institutions in EU countries.

The major differences between particular fiscal institutions concern not only the scope of tasks, but also the legal basis of their activity (the constitution, e.g. in Slovakia, Italy, or Estonia; parliamentary acts in most countries; government decision in Croatia), duration of the term ( 3 years in Sweden; 6 years, e.g. in the Czech Republic, Spain, or Latvia; 9 years in the Netherlands and Romania), the number of decision makers (e.g. three in Cyprus and Hungary, five in Greece and Romania, eleven 
in France, twenty-six in Denmark), the budget size (in three, the Maltese, Irish, and Italian ones, the acts which established them predetermined minimal levels of financing), and above all their impact on the course of budget processes. Since 2015, the European Commission has been quantifying the strength of particular fiscal institutions using the SIFI index (Scope Index of Fiscal Institutions), which defines the scope and position of these institutions in shaping and assessing fiscal policies. The data concerning this index indicate strong positions of these institutions in Spain and Great Britain and a low position in Slovenia.

TABLE 1

Sets of tasks realised by independent fiscal institutions in EU countries

\begin{tabular}{|l|l|}
\hline \multicolumn{1}{|c|}{ Task type } & \multicolumn{1}{c|}{ Examples of countries } \\
\hline Preparation of macroeconomic forecasts & $\begin{array}{l}\text { Austria, Belgium, Netherlands, } \\
\text { Slovenia }\end{array}$ \\
\hline Preparation of budget forecasts & $\begin{array}{l}\text { Belgium, Netherlands, Denmark, } \\
\text { Greece, Romania }\end{array}$ \\
\hline The assessment of the compliance with fiscal rules & $\begin{array}{l}\text { All EU countries with independent } \\
\text { fiscal institutions }\end{array}$ \\
\hline $\begin{array}{l}\text { Valuation of the costs of introduced fiscal reforms } \\
\text { (both in terms of taxes and expenditure) }\end{array}$ & Netherlands, Italy, Great Britain \\
\hline Analysis of long-term balance of public finance & Ireland, Portugal, Slovakia \\
\hline Promotion of fiscal transparency & Spain, Romania, Sweden, Slovakia \\
\hline Development of recommendations for fiscal policy & Austria, Sweden, Latvia \\
\hline
\end{tabular}

Source: author's own work on the basis of [Independent fiscal institutions database].

\section{Diversification of fiscal rules in EU countries}

The increasing role of fiscal rules and reinforcement of medium-term budget planning in the countries of the European Union causes a proliferation of applied solutions. As regards fiscal rules, the basic diversifying criteria include: the legal basis of the rule, the type of budget parameter on which the rule is based, the subject range of the rule, and the type of correction used in the event of non-compliance with the rule.

Therefore, among fiscal rules there are ones standardised in the constitution (e.g. the debt rules in Bulgaria, Poland, or Malta), provided for by legislative acts (the majority), but also those based on coalition agreements or political declarations (Belgium, the Netherlands, Ireland, or Finland). Among the existing fiscal rules, budget balance rules prevail, although it should be noted that the parameters included in these rules may be both absolute budget balances (which is chiefly the case in local government rules, e.g. in Germany, Finland, Italy, or Poland), budget balance in relation to GDP (e.g. in Bulgaria there is a rule which implies the deficit limit for the general government sector at $2 \%$ of GDP), or structural balance in relation to GDP 
(Belgium, Cyprus, Denmark, Latvia, and Slovakia), or even primary balance to GDP (Greece). As far as debt rules are concerned, they usually regard GDP, while in case of local government rules there are also those which specify the nominal level of debt (Bulgaria and Portugal), debt in relation to budget incomes (Estonia and Romania), or the amount of funds for debt service (Poland). Among expenditure rules, there are ones referring to the nominal level of expenditure (Austria, Romania, Slovakia), to increases in real-terms expenditure (Finland, Italy, Holland), and to expenditure in relation to GDP (Bulgaria). Income rules indicate the manner of allocating the revenues earned in a given budget year above the anticipated level. In the Netherlands, this means the necessity to allocate $75 \%$ of the budget surplus to pay the debt provided that the surplus is of a lasting nature in medium term, reserving the possibility to finance tax reductions from the remaining $25 \%$ of the surplus.

Table 2 presents the number of fiscal rules in the countries of the European Union along with examples of countries where the rules of a given type are used.

TABLE 2

\section{Types of fiscal rules in EU countries according to data from the end of 2016}

\begin{tabular}{|l|c|c|l|}
\hline \multicolumn{1}{|c|}{ Type of rule } & $\begin{array}{c}\text { Number of rules } \\
\text { (including the rules } \\
\text { for GG or CG sector) }\end{array}$ & $\begin{array}{c}\text { Number } \\
\text { of countries }\end{array}$ & \multicolumn{1}{|c|}{ Examples of countries } \\
\hline Budget balance rules & $56(33)$ & 26 & $\begin{array}{l}\text { Belgium, Denmark, Greece, } \\
\text { France, Sweden, Romania }\end{array}$ \\
\hline Debt rules & $23(16)$ & 16 & $\begin{array}{l}\text { Bulgaria, Cyprus, Hungary, } \\
\text { Ireland, Poland, Portugal }\end{array}$ \\
\hline Expenditure rules & $21(16)$ & 17 & $\begin{array}{l}\text { Austria, Croatia, Bulgaria, } \\
\text { Denmark, Spain, Italy }\end{array}$ \\
\hline Income rules & $5(4)$ & 3 & $\begin{array}{l}\text { France, Lithuania, } \\
\text { Netherlands }\end{array}$ \\
\hline
\end{tabular}

Source: [Fiscal rules database].

The differences in the subjective scope of rules mean that among them there are rules that apply to the entire general government sector as well which apply only to the central government sector, local government units, regional level, or the social insurance sector. If the rules are contravened, corrective activities, precisely defined in the law (for the debt rule in Bulgaria, Spain, Portugal, and Poland), can be implemented automatically, or the government is obliged to undertake corrective activities without legal specification of their character (Latvia, the Netherlands, Sweden, and Malta). However, there are examples of rules the contravention of which does not result in the necessity to undertake corrective activities (e.g. Bulgaria, Denmark, Finland, or Great Britain).

It should be added that also the number of rules used varies across the EU countries, as table 3 shows. This means that in some countries only one rule has been established (in Greece, a budget balance rule was established in 2014; in Croatia 
- an expenditure rule was introduced in 2016), while in other countries the number of rules is high (nine in Bulgaria, most of which have been in force since 2015; seven in Italy and Portugal).

Number of fiscal rules in particular EU countries

TABLE 3

\begin{tabular}{|l|l|}
\hline $\begin{array}{c}\text { Number } \\
\text { of rules }\end{array}$ & \multicolumn{1}{|c|}{ Countries } \\
\hline 4 and more & $\begin{array}{l}\text { Poland, Portugal, Romania, Belgium, Bulgaria, Germany, Finland, Ireland, } \\
\text { Italy, Lithuania, Netherlands, Slovakia }\end{array}$ \\
\hline 3 & $\begin{array}{l}\text { Denmark, Estonia, Spain, France, Hungary, Luxembourg, Sweden, Great } \\
\text { Britain, Czech Republic }\end{array}$ \\
\hline 2 & Austria, Cyprus, Latvia, Slovenia, Malta \\
\hline 1 & Greece, Croatia \\
\hline
\end{tabular}

Source: [Fiscal rules database].

The importance of fiscal rules is confirmed by the value of the index of fiscal rules published by the European Commission for particular countries, taking into consideration both the characteristics of fiscal rules and their number. The data from 2016 show that were Bulgaria and Italy countries with strong fiscal rules (chiefly because many various rules were in force there), while in the Czech Republic and Croatia, fiscal rules played an insignificant role in fiscal policies.

\section{Diversification of medium-term fiscal frameworks in European Union countries}

Considerable differences can be observed in the construction of medium-term budgetary frameworks. This regards such aspects as: the degree of involvement of particular levels of government in the process of creating them, the time horizon of planning, the range of general government covered by the frameworks, or the level of their precision.

In most EU member states, medium-term budgetary frameworks are prepared by the government; if they are submitted to parliaments, it is only for information purposes. However, in some countries they are authorised by parliament (e.g. Austria, Czech Republic, France, Greece, Latvia, and Sweden).

The time horizon specified by the frameworks is often consistent with the threeyear period indicated as the minimum period in the Directive 2011/85/UE, although there are examples of countries using a four-year old period (Austria, Denmark, Estonia, Finland, Germany, Greece, Italy, Luxembourg, the Netherlands, and Portugal). The frameworks are usually rolling frameworks, which means that every year, they are updated to the next year. In the case of Finland, the Netherlands and 
Great Britain, the time frameworks of plans are closed and are defined by the duration of parliamentary term.

Medium-term budgetary frameworks, moreover, vary widely as to the degree of specificity. The indicator of this feature is usually the specific character of fiscal rules in particular countries, determining the level of specificity of given budget parameters. For example, in Sweden and Finland attention is paid mainly to the overall expenditure of the central government sector. In the Netherlands, apart from the overall limit of expenditure for the central government sector, there are limits for expenditures in the social insurance sector and the health care system. In several countries, multi-annual limits are defined at the level of particular ministries (Cyprus, Greece, France, Ireland, and Great Britain). Additionally, in some cases, the first years of multi-annual plans are described in more detail than the subsequent years. In France, there is a total limit of expenditure for particular sub-sectors in the horizon of five years, but the first three years are comprised by expenditure limits ascribed to30 sections of the government sub-sector.

Another vital issue is the degree of links between multi-annual frameworks and the budget passed each year. The closest links can be observed in Sweden and Finland. Although in Finland specific limits refer to the real values (thus the ultimate level of expenditure is influenced by the inflation level), both in Sweden and Finland the limit of expenditures specified within medium-term frameworks may be subject to change only when government changes. It should be noted, however, that these limits are not legally binding being a result of political settlements (coalition agreement), but in both countries politicians are mindful to the cost of potential loss of reputation should the limits be breached. In such countries as Germany, Croatia, Slovakia and Slovenia, governments are in no way restricted by the limits specified in medium-term budgetary frameworks and can abandon them at any time without having to explain this to the public opinion. In Poland, the Multiannual State Financial Plan is merely a basis for preparing the budget act for the new fiscal year, but it is worth emphasising that after the end of the budget year, ministers are obliged to provide the Minister of Finance with information on the realisation of objectives along with the measuring tools for assessing the degree of their implementation as regards the main functions of the state. These solutions situate Poland's medium-term budgetary frameworks in the group of countries (along with, e.g. the Czech Republic, Spain, France, or Great Britain) the governments of which can, during the fiscal year, discretionally change the limits specified in the multiannual plan, provided that the public opinion receives an justification of the reasons for the decision. This means that medium-term budgetary frameworks in most EU countries are merely indicative. The importance of budget planning beyond the budget year in particular countries is reflected in the value of the medium-term budgetary framework index, annually published by the European Commission (MTBF Index). In accordance with data for 2016, the countries with high-quality medium-term budget planning included: Romania, the Netherlands, and Latvia, while Hungary, the Czech Republic, and Poland were assessed to have the lowest quality. 


\section{Conclusions}

A vast amount of research shows that, in practice, particular instruments of public finance governance have a complementary character. Therefore, institutional changes in terms of finance management in particular countries in recent years can only be discussed when the strength of particular instruments has been compared. Thus, what may be useful are the indexes, published by the European Commission, of the strength of fiscal rules, as well as the indexes of the quality of medium-term budgetary frameworks. When comparing the changes in the values of these indexes between 2015 and 2008, one may observe that among 9 EU member states whose public debt in 2008 exceeded $60 \%$ of their GDPs, in seven of them there was recorded a substantial increase in the importance of fiscal rules or medium-term budgetary frameworks. Only Austria and Belgium did not enjoy considerable improvement in this sphere, but it needs to be emphasised that Belgium is a country where the quality of medium-term budgetary frameworks for many years has been assessed as high, whereas Austria's independent fiscal institutions are quite robust. Furthermore, it should be said that countries which in the years 2008-2015 reported substantial increases in public debt in relation to GDP undertook activities aimed at reinforcing the role of finance management instruments (through strengthening fiscal rules - e.g. Ireland and Portugal, establishment and reforming of independent fiscal institutions - e.g. Spain and Greece, reinforcement of medium-term budgetary frameworks - e.g. Cyprus, Greece, or Portugal). Only in the case of Slovenia and Croatia, no substantial advancement in this area was observed.

The analysis of the solutions used in particular countries reveals the lack of a uniform model of the functioning of particular public finance governance instruments in the EU countries. At the same time, it can be concluded that the most dynamic changes of these instruments in recent years have been observed in those countries which had experienced considerable fiscal tensions.

\section{References}

Alesina A., Bayoumi T., 1996, The costs and benefits of fiscal rules: evidence from US states, NBER Working Paper, no. 5614.

Abbas A.S.M., Basdevant O., Eble S., Everaert G., Gottschalk J., Hasanov F., Park J., Sancak C., Velloso R., Villafuerte M., 2010, Strategies for Fiscal Consolidation in the Post-Crisis World, IMF, Washington.

Annett A., 2006, Enforcement and the Stability and Growth Pact: How Fiscal Policy Did and Did not Change under Europe's Fiscal Framework, Working Paper, no. 06/116, IMF.

Arezki R., Ismail K., 2013, Boom-Bust Cycle, Asymmetrical Fiscal Response and the Dutch Disease, "Journal of Development Economics", vol. 101, DOI: 10.1016/j. jdeveco.2012.11.007.

Badinger H., Reuter W.H., 2017, The case for fiscal rules, "Economic Modelling", vol. 60, DOI: 10.1016/j.econmod.2016.09.028. 
Beetsma R., Bluhm B., Giuliodori M., Wierts P., 2011, From First-Release to Ex-Post Fiscal Data: Exploring the Sources of Revision Errors in the EU, CEPR Discussion Paper no. DP8413.

Beetsma R., Giuliodori M., Wierts P., 2009, Planning to Cheat: EU Fiscal Policy in Real Time, "Economic Policy", vol. 24, DOI: 10.1111/j.1468-0327. 2009.00230.x.

Bergman U. M., Hutchison M., 2015, Economic Stabilization in the Post-Crisis World: Are Fiscal Rules the Answer?, "Journal of International Money and Finance", vol. 52, DOI: $10.1016 /$ j.jimonfin.2014.11.014.

Brzozowski M., Siwińska-Gorzelak J., 2010, The Impact of Fiscal Rules on Fiscal Policy Volatility, "Journal of Applied Economics", vol. 13, DOI: 10.1016/ S1514-0326 (10)60010-4.

Debrun X., Kinda, T., 2014, Strengthening post-crisis fiscal credibility-fiscal councils on the rise: $A$ new dataset, IMF Working Paper, no. 14/58.

Dessus S., Diaz Sanchez J.L., Varoudakis A., 2013, Fiscal Rules and the Procyclicality of Public Investment in the West African Economic and Monetary Union, The World Bank Policy Research Working Paper Series, no. 6562.

Fiscal rules database, European Commission, https://ec.europa.eu/info/publications/fiscal-rules-database_en.

Frankel J., Schreger J., 2013, Over-optimistic official forecasts and fiscal rules in the Eurozone, "Review of World Economics", vol. 149, no. 2.

Guerguil M., Mandon P., Tapsoba R., 2017, Flexible Fiscal Rules and Countercyclical Fiscal Policy, "Journal of Macroeconomics", vol. 52, DOI: 10.1016/j.jmacro. 2017.04.007.

Heinemann F., Osterloh S., Kalb, A., 2014, Sovereign risk premia: The link between fiscal rules and stability culture, "Journal of International Money and Finance", vol. 41, DOI: 10.1016/j.jimonfin.2013.11.002.

Holm-Hadulla F., Hauptmeier S., Rother P., 2012, The impact of numerical expenditurerules on budgetary discipline over the cycle, "Applied Economics", vol. 44, DOI: 10.1080/00036846.2011.572855.

Independent fiscal institutions, European Commission, https://ec.europa.eu/info/businesseconomy-euro/indicators-statistics/economic-databases/fiscal-governance-eumember-states/independent-fiscal-institutions_en.

Jonung L., Larch M., 2006, Improving Fiscal Policy in the EU: The Case for Independent Forecasts, "Economic Policy", vol. 21, no. 47.

Moulin L., Wierts P., 2006, How Credible Are Multiannual Budgetary Plans In The EU?, SSRN, DOI: $10.2139 / \operatorname{ssrn} .2005228$.

Nerlich C., Reuter W.H., 2013, The design of national fiscal frameworks and their budgetary Impact, ECB Working Paper 1588, Frankfurt am Main.

Piotrowska-Marczak K., 2011, Współczesne kierunki zarzqdżania finansami publicznymi, [w:] Instrumenty nowego zarzadzania finansami publicznymi w wybranych krajach Unii Europejskiej, Temida 2, Bialystok.

Postuła M., 2015, Instrumenty zarzadzania finansami publicznymi, Wydawnictwo Naukowe Wydziału Zarządzania UW, Warszawa. 
Strauch R., Hallerberg M., von Hagen J., 2004, Budgetary Forecasts in Europe - the Track Record of Stability and Convergence Programmes, ECB Working Paper, no. 307, Frankfurt am Main.

Tapsoba R., 2012, Do National Numerical Fiscal Rules Really Shape Fiscal Bebaviours in Developing Countries? A Treatment Effect Evaluation, "Economic Modelling", vol. 29(4), DOI: 10.1016/j.econmod.2012.03.003.

Vlaicu R., Verhoeven M., Grigoli F., Mills Z., 2014, Multiyear budgets and fiscal performance: Panel data evidence, "Journal of Public Economics", vol. 111, DOI: 10.1016/ j.jpubeco.2013.12.011.

von Hagen J., 2010, Sticking to Fiscal Plans: The Role of Fiscal Institutions, "Public Choice", vol. 144(3-4). 